\title{
EFFECT OF MODIFIED ATMOSPHERE AND VACUUM PACKAGING CONDITIONS ON SELECTED CHEMICAL AND PHYSICO-CHEMICAL PARAMETERS OF MARINATED AND SALTED ATLANTIC MACKEREL (Scomber scombrus)
}

\author{
Jelena S. Ivanović ${ }^{1 *}$, Jelena M. Janjić ${ }^{\text {, Slaven M. Grbić }}{ }^{2}$, Jasna P. Đorđević ${ }^{1}$, Nataša M.Glamočlija ${ }^{1}$, \\ Tatjana M.Baltić ${ }^{3}$, Radmila V. Marković ${ }^{1}$, Marija D.Bošković ${ }^{1}$, Milan Ž. Baltić ${ }^{1}$ \\ ${ }^{1}$ Department of Food Hygiene and Technology, Faculty of Veterinary Medicine, University of Belgrade, \\ Bulevar oslobođenja 18, 11000 Belgrade, Serbia \\ ${ }^{2}$ Slaven d.o.o, Banja Luka, Bosnia and Herzegovina \\ ${ }^{3}$ Institute of Meat Hygiene and Technology, Kaćanskog 13, 11000 Belgrade, Serbia
}

\author{
*Corresponding author: \\ Phone: +381606696861 \\ E-mail address: 1310jecko@gmail.com
}

\begin{abstract}
Chemical and physico-chemical parameters of marinated and salted Atlantic mackerel (Scomber Scombrus), with emphasis on the quality and safety parameters in modified atmosphere packaging (MAP) and vacuum packaging (VP), were investigated. Quality assessment of mackerel stored in MAP $\left(40 \% \mathrm{CO}_{2}+60 \% \mathrm{~N}_{2}\right)$ and VP for up to 50 days at $4 \pm 1{ }^{\circ} \mathrm{C}$ was done by the monitoring of $\mathrm{pH}$ value, total volatile basic nitrogen (TVB-N), thiobarbituric acid (TBA) and histamine. The $\mathrm{pH}$ value of fish meat was significantly lower in the marinated samples. The highest concentration of TVB-N was recorded in the salted mackerel stored under VP whereas the lowest TVB-N in the marinated mackerel stored under MAP conditions. The formation of TBA increased with the time of storage and was the lowest in the marinated mackerel stored in MAP. The concentration of histamine increased during storage and its level reached over $10 \mathrm{mg} / 100 \mathrm{~g}$ for the salted mackerel stored under VP conditions. The marinated mackerel packed in MAP had extended shelf life at $4 \pm 1{ }^{\circ} \mathrm{C}$ compared to that packaged in VP according to physico-chemical analysis.
\end{abstract}

Key words: Atlantic mackerel, histamine, $p H$ value, TBA, TVB-N

\section{INTRODUCTION}

Fish is one of the most perishable food products and the shelf life of such products is limited in the presence of air by the chemical effects of atmospheric oxygen and the growth of aerobic spoilage microorganisms (Ivanović et al., 2014). Modification of the atmosphere within the package by decreasing the oxygen concentration, while increasing the content of carbon dioxide and/or nitrogen has been shown to significantly prolong the shelf life of perishable food products at chill tem- peratures (Ivanović et al., 2015; Özoğul et al., 2004). Modified atmosphere packaging (MAP) and vacuum-packaging (VP), along with refrigeration temperature, have become increasingly popular preservation techniques, which have brought major changes in storage, distribution and marketing of raw and processed products. MAP and VP systems could provide further improvement in seafood shelf life, organoleptic quality, and product range (Koral et al., 2010). 
Marinades are salty-sour unpasteurized products, produced with adequate technological methods, with brine, acetic acid, sauce or oil, etc. (Stamatis and Arkoudelos, 2007; Siverstvik et al., 2007). Marinated products, in most cases, require an additional, usually, heat treatment (Sandhya, 2010), but under certain conditions (depending on the duration of marinating, amount of salt, acid and type of fish) marinated products can be "ready-to- eat" products (Mendes and Goncalvez, 2008; Rivas et al., 2008). The inhibitory effect of marinade depends on the concentration of acid and salt. Marinated fish at the refrigeration temperature $\left(4-6{ }^{\circ} \mathrm{C}\right)$ can be stored for up to several months, depending on the concentration of salts and acids (Babić et al., 2013; Cadun et al., 2005).

Thiobarbituric acid (TBA) content (Tozawa et al., 1971) and total volatile basic nitrogen (TVB-N) (Antonacopoulos and Wilfried, 1989) have been proposed as indicators of fish quality deterioration (Luong et al., 1992). Levels of biogenic amines can also be useful in estimating freshness or spoilage degree of fish since their formation is associated with bacterial spoilage (Mackie et al., 1997).

Fish containing relatively high concentrations of histamine can cause poisoning or allergic reactions when consumed by some individuals. Histamine is produced by microbial decarboxylation of the amino acid histidine (Cabrer et al., 2002). The importance of estimating the concentration of histamine in fish and fish products is related to its impact on human health and food quality. Histamine formation in MAP has been found to be lower than in the air (Özoğul et al., 2002; Watts and Brown, 1982).

The effects of modified atmosphere packaging and vacuum conditions on fish have been reviewed extensively but little information is available on the storage of Atlantic mackerel under modified atmosphere and vacuum packing conditions. Therefore, the main objective of this study was to investigate the effects of modified atmosphere and vacuum on the quality and safety of the Atlantic mackerel. Quality attributes were assessed by different me- thods, including physico-chemical evaluation.

\section{MATERIAL AND METHODS}

Raw material, sampling and processing

Frozen Atlantic mackerel (Scomber scombrus) was used for the experiment. Fish was taken from the local fish company (Squadra.rs), commercial size, weight between 350 and $400 \mathrm{~g}$ and processed in a common way for the fish processing plant. They were immediately eviscerated and divided into four groups. The first group was treated with brine ( $10 \%$ of salt), and was packed under a vacuum, the second group was treated with brine (10\% of salt) and packed under the modified atmosphere $\left(40 \% \quad \mathrm{CO}_{2} / 60 \% \quad \mathrm{~N}_{2}\right)$. The third group was marinated in a solution containing $10 \%$ salt and $0.5 \%$ of acetic acid and was packed in a vacuum. The fourth group was marinated with solution containing $10 \%$ of salt and $0.5 \%$ of acetic acid and was packed in the modified atmosphere $\left(\begin{array}{lllll}40 \% & \mathrm{CO}_{2} / 60 \% & \mathrm{~N}_{2}\end{array}\right)$. The marinating process lasted 24 hours. All samples were stored under the same conditions, at the temperature of $4 \pm 1{ }^{\circ} \mathrm{C}$. For the packaging of samples, a packing machine "Variovac" (Variovac Primus, Zarrentin, Germany) was used. The samples were packed in OPA/EVOH/PE (oriented polyamide/ethylene vinyl alcohol/polyethylene foil (Dynopack, POLIMOON (Kristiansand, Norway), characterized with low permeability to gas. The degree of permeability to $\mathrm{O}_{2}$ was 3.2 $\mathrm{cm}^{3} / \mathrm{m}^{2}$ / day at $23^{\circ} \mathrm{C}$, to $\mathrm{N}_{2} 1 \mathrm{~cm}^{3} / \mathrm{m}^{2} /$ day at $23{ }^{\circ} \mathrm{C}$, to $\mathrm{CO}_{2} 14 \mathrm{~cm}^{3} / \mathrm{m}^{2} /$ day at $23^{\circ} \mathrm{C}$, and to water vapor $15 \mathrm{~g} / \mathrm{m}^{2} /$ day at $38^{\circ} \mathrm{C}$. The gas / sample ratio in the package was $2: 1$. Six fish were removed from each batch for each sampling day but data were obtained using three samples $(3 \times 2)$ for chemical analysis (two fish minced for each sampling).

\section{Analysis}

Samples were stored at $4{ }^{\circ} \mathrm{C}$ and examined at day(s) 0, 10, 20, 30, 40 and 50 . Moisture content was determined by oven drying of $5 \mathrm{~g}$ of fish muscle at $105^{\circ} \mathrm{C}$ until a constant weight was obtained (AOAC, 1995, Method 985.14). Results were expressed as $\mathrm{g}$ water/100 $\mathrm{g}$ muscle. Ash 
content was determined by the AOAC (1980) method 7.009. The crude fat content was determined using a solvent extractor Velp SER 148/6 (Velp Scientifica, Milano, Italy) with petroleum ether $\left(130{ }^{\circ} \mathrm{C}\right)$ and protein content was determined by AOAC (1980) method 2.507. The method according to Mohr was used to determine salt content $(\mathrm{NaCl})$ in fish muscle as described in Keskin (1982). Chemical analysis of Atlantic mackerel (moisture, ash, salt, fat and protein content) were performed at the beginning of the experiment ( 0 day). $\mathrm{pH}$ value was measured with pH Meter "Testo 205" (Testo AG, Lenzkirch, Germany).

The method of Lucke and Geidel was used to determine TVB-N (Total Volatile Basic Nitrogen) content as described by Inal (1992). TBA (thiobarbituric acid) values, expressed in $\mathrm{mg}$ of malonaldehyde/kg, were estimated by using the method of Tarladgis et al. (1960) which is described by Smith et al. (1992) and Varlik et al. (1993).

Histamine quantification in fish muscle was carried out by the colorimetric method of Patange et al. (2005), based on the interaction between the imidazole ring and p- phenyldiazonium sulfonate. The concentration of histamine in the sample was obtained from the standard curve and expressed as $\mathrm{mg}$ per $100 \mathrm{~g}$ of wet weight (mg/100 g W.W).

\section{Statistical Analysis}

The obtained data were analyzed by analysis of variance (ANOVA) and when significant differences were found, comparisons among means were carried out by using theTukey test $(P<0.01 ; P<0.05)$. Statistical analysis of the results was performed using software GraphPad Prism version 5.00 for Windows, GraphPad Software, San Diego, California USA, www.graphpad.com.

\section{RESULTS AND DISCUSSION}

Table 1 shows the moisture, protein, lipid, ash and salt contents of raw, salted and marinated Atlantic mackerel. Differences between moisture, lipid, ash and salt contents of raw, salted and marinated Atlantic mackerel were found to be significant $(P$ $<0.01$; $P<0.05$ ), but the differences between protein content were not found to be significant $(P>0.05)$. Baltić and Teodorović (1997) reported that the chemical composition of Atlantic mackerel was $74.5 \%$ water, $20.7 \%$ protein and $3.4 \%$ lipid. Also, Mbarki et al. (2009) reported in their experiment that moisture was $71.78 \%$, ash $2.26 \%$, protein $21.38 \%$ and fat $4.13 \%$. The variation of the Atlantic mackerel chemical composition is closely related to nutrition, living area, fish size, catching season, sexual variations as well as other environmental conditions (Baltić and Teodorović, 1997).

Table 1.

Chemical composition of Atlantic mackerel (mean \pm standard deviation)

\begin{tabular}{cccc}
\hline Parameters (\%) & Raw fish & Salted mackerel & Marinated mackerel \\
\hline Protein content & $20.05 \pm 0.94$ & $19.94 \pm 0.81$ & $19.95 \pm 0.90$ \\
Lipid content & $9.56^{\mathrm{AB}} \pm 0.41$ & $10.40^{\mathrm{AC}} \pm 0.38$ & $11.40^{\mathrm{BC}} \pm 0.56$ \\
Moisture content & $69.17^{\mathrm{Aa}} \pm 1.25$ & $66.24^{\mathrm{a}} \pm 2.18$ & $65.13^{\mathrm{A}} \pm 1.84$ \\
Ash content & $1.12^{\mathrm{AB}} \pm 0.05$ & $2.92^{\mathrm{AC}} \pm 0.09$ & $3.46^{\mathrm{BC}} \pm 0.08$ \\
Salt content & $0.10^{\mathrm{AB}} \pm 0.05$ & $1.80^{\mathrm{AC}} \pm 0.011$ & $2.34^{\mathrm{BC}} \pm 0.13$ \\
\hline Legend: Within a row, means with a common superscript letters are significantly different: ${ }^{\mathrm{A}-\mathrm{C}}(P<0.01)$ and ${ }^{a}(P$ \\
$<0.05)$
\end{tabular}

Table 2.

$\mathrm{pH}$ value of packaged Atlantic mackerel (mean \pm standard deviation)

\begin{tabular}{|c|c|c|c|c|c|c|}
\hline \multirow[b]{2}{*}{ Group } & \multicolumn{6}{|c|}{ Days of storage ( $\bar{X} \pm S D)$} \\
\hline & 0 & $10^{\mathrm{th}}$ & $20^{\text {th }}$ & $30^{\text {th }}$ & $40^{\text {th }}$ & $50^{\mathrm{th}}$ \\
\hline I & $6.14^{\mathrm{AB}} \pm 0.04$ & $5.56^{\mathrm{aAB}} \pm 0.05$ & $5.33^{A B} \pm 0.05$ & $5.16^{A B C} \pm 0.03$ & $5.09^{A B C} \pm 0.02$ & $4.80^{A B C} \pm 0.07$ \\
\hline II & $6.14^{\mathrm{Cu}} \pm 0.04$ & $5.66^{\mathrm{aCu}} \pm 0.07$ & $5.42^{\mathrm{CU}} \pm 0.03$ & $5.29^{\mathrm{ADE}} \pm 0.05$ & $5.30^{\mathrm{AUt}} \pm 0.04$ & $5.00^{\mathrm{AUt}} \pm 0.09$ \\
\hline III & $5.09^{A C} \pm 0.06$ & $4.81^{\mathrm{ACD}} \pm 0.05$ & $4.59^{\mathrm{ACE}} \pm 0.08$ & $4.50^{\mathrm{BU}} \pm 0.06$ & $4.50^{\mathrm{BL}} \pm 0.06$ & $4,47^{\mathrm{BU}} \pm 0.04$ \\
\hline IV & $5.09^{\mathrm{BD}} \pm 0.06$ & $4.72^{\mathrm{BUb}} \pm 0.03$ & $4.44^{\mathrm{BUt}} \pm 0.05$ & $4.43^{\mathrm{CL}} \pm 0.05$ & $4.50^{\mathrm{Ct}} \pm 0.11$ & $4.43^{\mathrm{CE}} \pm 0.04$ \\
\hline
\end{tabular}
$(P<0.05)$

Group I: salted mackerel-vacuum; Group II: salted mackerel - MAP; Group III: marinated mackerel-vacuum; Group IV: marinated mackerel - MAP 
The results of average $\mathrm{pH}$ value in the samples of Atlantic mackerel, packaged in modified atmosphere and under vacuum conditions, are shown in Table 2. The initial $\mathrm{pH}$ value of muscle was $6.14 \pm 0.04$ in salted and $5.09 \pm 0.06$ in marinated mackerel.

During the storage period the $\mathrm{pH}$ value decreased, but $\mathrm{pH}$ value is not only criteria of spoilage (Kilinc and Cakli, 2005). After the marinating process, the $\mathrm{pH}$ values decreased sharply from $5.09 \pm 0.06$ to $4.47 \pm 0.04$ (VP) and $4.43 \pm 0.04$ (MAP) for marinated mackerel. A significant differrence $(P<0.01 ; P<0.05)$ was found in $\mathrm{pH}$ value between some groups (Table 2). Aksu et al. (1997) reported that $\mathrm{pH}$ value in anchovy marinated with $2 \%$ and $4 \%$ acetic acid increased from 4.25 and 4.18 to 4.53 and 4.31 , respectively. In mackerel, red muscle is well developed and contains more glycogen than white muscle (Shimizu et al., 1992). It appears that the breakdown of glycogen to lactic acid of fish after capture, especially in mackerel, makes pH lower (Sainclivier, 1983). Poligne and Collignan (2000) determined that the $\mathrm{pH}$ value of fish increased from 3.90 to 4.21 after 2 days of storage, and then remained constant until the end of storage (50 ${ }^{\text {th }}$ day). Kilinc and Cakli (2004) found that $\mathrm{pH}$ value of marinated sardine samples packaged in MAP significantly decreased with prolonged storage. Some literature data indicate that $\mathrm{pH}$ value increases during storage when fish is not treated (marinated, salted) (Losada et al., 2003). Small increases in $\mathrm{pH}$ values have been reported for Atlantic mackerel stored in slurry ice (Banks et al., 1980). The reported data indicate that $\mathrm{pH}$ values of the MAP and vacuum packed samples were significantly lower $(P<0.05)$ through-out the storage period. For MAP-stored fish it is well known that carbon dioxide can be absorbed into fish muscle surface, acidifying it via the formation of carbonic acid (Losada et al., 2003).

The European Union directive on fish hygiene specifies that if the organoleptic examination reveals any doubt as to the freshness of the fish, inspectors must use TVB$\mathrm{N}$ as a chemical check (EU 91/493/EEC,
1991). TVB-N as an indicator of freshness is a measurement of the amount of basic volatile compounds recovered by distilling fish muscle, or extracts of fish muscle, under alkaline conditions (Howgate, 2010). In literature, different TVB-N values were suggested for the freshness of fish and fish products; however, maximum limit 35 $\mathrm{mg} / 100 \mathrm{~g}$ is generally acceptable (Connell, 1990; Lopez-Caballero et al., 2000; Kim et al., 2002). TVB-N values increased significantly at all experimental groups $(P<0.05)$ (Table 3). TVB-N values of samples stored at $4 \pm 1{ }^{\circ} \mathrm{C}$ were just over the maximum value at the $50^{\text {th }}$ day, $38.49 \pm 0.38 \mathrm{mg} / 100 \mathrm{~g} \mathrm{(I}$ group). Therefore, packaging in MAP conditions provided improvement in terms of quality relating to TVB-N values. The more rapid increase of TVB-N at higher microbial numbers indicated the stage of substantial spoilage of the fish.

Fraser and Sumar (1998) indicated that bacterial catabolism of amino acids in fish muscle results in the accumulation of ammonia and other volatile bases. The statistical analysis of the TVB-N showed significant differences $(P<0.01)$ between the TVB-N values at different stages of storage of fish in VP and MAP. As for many fish species, the formation of TVB-N increased with time. During marinating, TVB-N content can be reduced due to the action of acids and salts which release nitric components from the fish, which migrate into the marinade (Günsen et al., 2011). Also, Kilinc and Cakli (2005) determined a considerable decrease in TVB-N, from 10.3 to $6.5 \mathrm{mg} / 100 \mathrm{~g}$, after marinating sardine fillets in a solution containing $7 \%$ acetic acid and $14 \%$ salt. During storage, a significant increase in TVN-B value was noticed. A similar pattern of increase in TVB-N values during refrigerated storage has been reported in marinated sardines (Gökoglu et al., 2004; Banks et al., 1980) and brined chub mackerel (Goulas et al., 2005). On the other hand, Pons-SanchezCascado (2005) reported that TVB-N levels in marinated fish in vinegar remained constant during two weeks of the marinating process, and throughout the storage period of 3 months under refrigerated vacuum-packed storage, as well. 
One of the other quality parameters is known as TBA and maximum allowed level is accepted as $8 \mathrm{mg}$ malonal-dehyde/kg (Schormüller, 1969). Salted fish and marinated fish contained 0.20 and $0.10 \mathrm{mg}$ malonaldehyde/kg, respectively (table 4). The values increased significantly in all samples $(P<0.01 ; P<0.05)$ although samples were within acceptable levels for this parameters. The content of malondialdehyde in vacuum packaging was higher than in samples packaged in MAP (Table 4).

Sallam et al. (2007) found that malondialdehyde values of Pacific saury in $2 \%$ and $3 \%$ acetic acid were 1.88 and $1.61 \mathrm{mg}$ $\mathrm{MDA} / \mathrm{kg}$, respectively, at the end of the storage period (90 days), reaching the maximum level after 70 days. Cadun et al. (2005) reported a malondialdehyde value of $6.50 \mathrm{mg} \mathrm{MDA} / \mathrm{kg}$ in marinated shrimp, after 40 days of storage.

Biogenic amine content in fish can be used to estimate freshness and degree of spoilage. These amines are found at low levels in fresh fish and their presence is associated with bacterial spoilage. The amount and type of amine formed depends on fish species, microbial flora and several parameters which influence bacterial growth during storage, such as temperature, packaging and antimicrobial agents Erkan and Özden (2008).The results for histamine content of the packed Atlantic mackerel samples during fifty days of storage are shown in Table 5.

In the present study, the content of histamine, the causative agent for fish poisoning, was $4.51 \pm 0.22 \mathrm{mg} / 100 \mathrm{~g}$ (I, II groups) and $4.55 \pm 0.21 \mathrm{mg} / 100 \mathrm{~g}$ (III, IV groups) at initial day (0 day).

Table 3

TVB-N values of packaged Atlantic mackerel $(\mathrm{mg} / 100 \mathrm{~g})$

\begin{tabular}{|c|c|c|c|c|c|c|}
\hline \multirow[b]{2}{*}{ Group } & \multicolumn{6}{|c|}{ Days of storage ( $\bar{X} \pm S D)$} \\
\hline & 0. & $10^{\mathrm{th}}$ & $20^{\text {th }}$ & $30^{\text {th }}$ & $40^{\text {th }}$ & $50^{\mathrm{th}}$ \\
\hline 1 & $10.15 \pm 0.40$ & $14.11^{\mathrm{AB}} \pm 0.59$ & $18.71^{\mathrm{ABC}} \pm 0.23$ & $25.43^{\mathrm{ABC}} \pm 0.34$ & $31.28^{\mathrm{ABC}} \pm 0.40$ & $38.49^{\mathrm{ABC}} \pm 0.38$ \\
\hline II & $10.15 \pm 0.40$ & $12.37^{\mathrm{ACD}} \pm 0.29$ & $17.10^{\mathrm{AUE}} \pm 0.15$ & $22.46^{\text {AUt }} \pm 0.26$ & $26.25^{\mathrm{AUt}} \pm 0.39$ & $32.26^{\mathrm{AUE}} \pm 0.36$ \\
\hline III & $10.15 \pm 0.40$ & $13.55^{\mathrm{CE}} \pm 0.26$ & $16.61^{\mathrm{BDF}} \pm 0.29$ & $20.43^{\mathrm{BDF}} \pm 0.34$ & $24.47^{\mathrm{BDF}} \pm 0.33$ & $30.03^{\mathrm{BDF}} \pm 0.59$ \\
\hline IV & $10.15 \pm 0.40$ & $11.54^{\mathrm{BUE}} \pm 0.22$ & $13.19^{\mathrm{CtEr}} \pm 0.26$ & $18.69^{\text {Cet }} \pm 0.36$ & $22.31^{\mathrm{C} \text { et }} \pm 0.30$ & $27.43^{\mathrm{CEt}} \pm 0.35$ \\
\hline
\end{tabular}

Legend: Within column, means with a common superscript letters are significantly different: ${ }^{A-D}(P<0.01) ;$ means without a superscript letters no significantly different

Group I: salted mackerel-vacuum; Group II: salted mackerel - MAP; Group III: marinated mackerel-vacuum; Group IV: marinated mackerel - MAP

Table 4

TBA in the packaged Atlantic mackerel (mg malonaldehyde/kg)

\begin{tabular}{ccccccc}
\hline & \multicolumn{7}{c}{ Days of storage $\bar{X} \pm$ SD } \\
\cline { 2 - 7 } Group & $\mathbf{0}$ & $\mathbf{1 0}^{\text {th }}$ & $\mathbf{2 0}^{\text {th }}$ & $\mathbf{3 0}^{\text {th }}$ & $\mathbf{4 0}^{\text {th }}$ & $\mathbf{5 0}^{\text {th }}$ \\
\hline I & $0.20 \pm 0.01$ & $0.84^{\mathrm{AB}} \pm 0.06$ & $1.30^{A B C} \pm 0.02$ & $1.67^{A B C} \pm 0.04$ & $1.80^{A B C} \pm 0.04$ & $2.10^{A B C} \pm 0.07$ \\
II & $0.20 \pm 0.01$ & $0.79^{\mathrm{ABC}} \pm 0.01$ & $1.21^{\mathrm{ADE}} \pm 0.02$ & $1.50^{\mathrm{AD}} \pm 0.04$ & $1.70^{\mathrm{Aa}} \pm 0.03$ & $1.89^{\mathrm{Aa}} \pm 0.02$ \\
III & $0.19 \pm 0.01$ & $0.73^{\mathrm{AD}} \pm 0.03$ & $1.04^{\mathrm{BDa}} \pm 0.06$ & $1.45^{\mathrm{BE}} \pm 0.04$ & $1.65^{\mathrm{BD}} \pm 0.04$ & $1.80^{\mathrm{BD}} \pm 0.06$ \\
IV & $0.19 \pm 0.01$ & $0.70^{\mathrm{BC}} \pm 0.01$ & $0.96^{\mathrm{CEa}} \pm 0.05$ & $1.35^{\mathrm{CDE}} \pm 0.04$ & $1.58^{\mathrm{CaD}} \pm 0.03$ & $1.69^{\mathrm{CaD}} \pm 0.06$ \\
\hline
\end{tabular}

Legend: Within column, means with a common superscript letters are significantly different: ${ }^{A-D}(P<0.01)$ and ${ }^{a, b}$ $(P<0.05)$ : means without a superscript letters no significantly different

Group I: salted mackerel-vacuum; Group II: salted mackerel - MAP; Group III: marinated mackerel-vacuum; Group IV: marinated mackerel - MAP

Table 5 .

Histamine content in the packaged Atlantic mackerel $(\mathrm{mg} / 100 \mathrm{~g})$

\begin{tabular}{ccccccc}
\hline \multirow{2}{*}{ Group } & \multicolumn{7}{c}{ Days of storage $\bar{X} \pm$ SD } \\
\cline { 2 - 7 } & $\mathbf{0}$ & $\mathbf{1 0}^{\text {th }}$ & $\mathbf{2 0}^{\text {th }}$ & $\mathbf{3 0}^{\text {th }}$ & $\mathbf{4 0}^{\text {th }}$ & $\mathbf{5 0}^{\text {th }}$ \\
\hline I & $4.51 \pm 0.22$ & $6.57^{\mathrm{ABC}} \pm 0.27$ & $7.34^{\mathrm{ABC}} \pm 0.29$ & $8.26^{\mathrm{ABC}} \pm 0.12$ & $9.38^{\mathrm{ABC}} \pm 0.17$ & $10.20^{\mathrm{ABC}} \pm 0.11$ \\
II & $4.51 \pm 0.22$ & $6.14^{\mathrm{AD}} \pm 0.12$ & $6.63^{\mathrm{ADE}} \pm 0.10$ & $6.96^{\mathrm{AD}} \pm 0.05$ & $7.77^{\mathrm{ADE}} \pm 0.14$ & $8.35^{\mathrm{ADE}} \pm 0.10$ \\
III & $4.55 \pm 0.21$ & $5.54^{\mathrm{BUE}} \pm 0.24$ & $6.61^{\mathrm{BU}} \pm 0.12$ & $6.87^{\mathrm{BE}} \pm 0.08$ & $7.14^{\mathrm{BU}} \pm 0.16$ & $7.74^{\mathrm{BU}} \pm 0.12$ \\
IV & $4.55 \pm 0.21$ & $5.41^{\mathrm{CE}} \pm 0.11$ & $5.69^{\mathrm{CEF}} \pm 0.09$ & $6.21^{\mathrm{CDE}} \pm 0.1$ & $6.40^{\mathrm{CEF}} \pm 0.09$ & $6.91^{\mathrm{CEF}} \pm 0.05$ \\
\hline
\end{tabular}

Legend: Within column, means with a common superscript letters are significantly different: ${ }^{A-D}(P<0.01):$ means without a superscript letters no significantly different

Group I: salted mackerel-vacuum; Group II: salted mackerel - MAP; Group III: marinated mackerel-vacuum; Group IV: marinated mackerel - MAP 
This value was higher than those found by Erkan and Özden (2008) for sardine (1.2 $\mathrm{mg} / 100 \mathrm{~g}$ ) ( $S$. pilchardus). This may be due to different fish species and catching area. The legal limits for histamine set by the EU Council Directive 91/493/EEC (1991) to as less than $10 \mathrm{mg} / 100 \mathrm{~g}$ have been reached by the group I after $50^{\text {th }}$ days. Ababouch et al. (1991) also reported that histamine reached toxic levels after 6-10 days in sardines (S. pilchardus) stored at $8{ }^{\circ} \mathrm{C}$ and on the ice. FDA (2011) confirmed the average con-centration of histamine in fish at $5 \mathrm{mg} / 100 \mathrm{~g}$ for health assurance of products, and more than this level is undesirable. The European Union has suggested that the average concentration of histamine in fish should not be more than $10 \mathrm{mg}$ of histamine per $100 \mathrm{~g}$ of fish muscle and it seems to be good for general health (Le-hane and Olley, 2000). As well as the SABS (South African Boreau of Standard) and AFSC (Australian Food Standard Code), respectively, 10 $\mathrm{mg} / 100 \mathrm{~g}$ and $20 \mathrm{mg} / 100 \mathrm{~g}$ of histamine levels in fish muscle have been suggested as a limit. Thus, the results of this study are consistent with international references. Fresh fish usually have low amount of histamine in the limit of $0.1 \mathrm{mg} / 100 \mathrm{~g}$. Red meat fishes, such as sardine and mackerel have higher levels of histamine compared with white meat fishes like cod and $\mathrm{Ha}$ mour.

Özoğul et al. (2008), reported that amounts of histamine in sardines (Sardina pilchardus) increased during storage and reached $14.0 \pm 1.2 \mathrm{mg}$ per $100 \mathrm{~g}$, in a vacuum, and $10.5 \pm 1.2 \mathrm{mg}$ per $100 \mathrm{~g}$, in MAP. Also, in this study the content of histamine increased during storage, and this phenomenon was more pronounced in samples packaged in a vacuum. Larger amount of histamine were determined in samples packaged in MAP with a lower content of $\mathrm{CO}_{2}$ (Duyar and Eke, 2009). Similar results were reported by other authors (Siverstvik, 2007).

\section{CONCLUSIONS}

At the end of this study, while the differrences between $\mathrm{pH}$ value, TVB-N, TBA and histamine value were statistically significant between pre-packaging treatment with acids and salt and packaging conditions (VP and MAP). MAP could improve some quality aspects and increased the shelf-life of fish especially of the marinated fish as compared with the salted fish packaged under the same conditions.

\section{ACKNOWLEDGEMENTS}

This paper was supported by the Ministry of Education, Science and Technological Development of the Republic of Serbia, Project "Selected biological hazards to the safety / quality of food of animal origin and the control measures from farm to consumer" (31034).

\section{REFERENCES}

1. Ababouch, L.H., Souibri, L., Rhaliby, K., Ouahdi, O., Battal, M., Busta, F.F. (1996). Quality changes in sardines (Sardina pilchardus) stored in ice and at ambient temperature. Food Microbiology, 13, 123132.

2. AOAC (1980). Official Methods of Analysis of AOAC International $13^{\text {th }}$ ed., Association of Official Analytical Chemists, Washington, DC, USA, Official Methods 7.009. and 2.507.

3. AOAC (1995). Official Methods of Analysis of AOAC International $16^{\text {th }}$ ed., AOAC International, Gaithersburg, MD, USA, Official Method 985.14.

4. Antonacopoulos, N., Wilfried V. (1989). Determination of volatile basic nitrogen in fish: a third collaborative study by the West European Fish Technologists' Association (WEFTA)." Zeitschrift für LebensmittelUntersuchung und Forschung, 189 (4), 309-316.

5. Aksu, H., Erkan, N., Colak, H., Varlik, C., Gokoglu, N., Ugur, M. (1997). Some changes in anchovy marinades during production in different acid-salt concentrations and determination of shelf life. Journal of the Faculty of Veterinary Medicine, 8, 86-90.

6. Babić, J., Dimitrijević, M., Milijašević, M., Đorđević, V., Petronijević-Grbić, S., Spirić, A. (2013). Effect of modified atmosphere and vacuum packaging on selected chemical parameters of rainbow trout (Oncorhynchus mykiss) and carp (Cyprinus carpio) cuts freshness. Chemical Industry, 68, 69-76.

7. Baltic, M., Teodorovic, V. (1997). Hygiene of Fish Meat, Crustaceans and Molluscs, Faculty of Veterinary Medicine, Belgrade.

8. Banks, H., Nickelson, R., Finne, G. (1980). Shelf life studies on carbon dioxide, packaged finfish from the Gulf of Mexico. Journal of Food Science, 45, 157162.

9. Cabrer, A., Casales, M., Yeannes, M. (2002). Physical and chemical changes in anchovy (Engraulis anchoita) flesh during marination. Journal of Aquatic Food Product Technology, 11, 19-31.

10. Cadun, A., Cakli, S. and Kisla, D. (2005). A study of marination of deepwater pink shrimp (Parapenaeus longirostris, Lucas, 1846) and its shelf life. Food Chemistry, 90, 53-59.

11. Connell, J.J. (1990). Methods of assessing and selecting for quality. In Control of fish quality. ( $3^{\text {rd }}$ ed.), Fishing News Books, Surrey, Oxford, England pp. 122-150.

12. Duyar, H.A., Eke, E. (2009). Quality determination of marinade from different fish species, Journal of Animal and Veterinary Advances, 8, 270-275. 
Jelena Ivanović et al., Effect of modified atmosphere and vacuum packaging conditions on selected chemical and physicochemical parameters of marinated and salted Atlantic mackerel (Scomber scombrus),

Food and Feed Research, 43 (1), 111-118, 2016

13. Erkan, N., Özden, Ö. (2008). Quality assessment of whole and gutted sardines (Sardina pilchardus) stored in ice. International Journal of Food Science \& Technology, 43, 1549-1559.

14. Council Directive 91/493/EEC (1991). Council Directive 91/493/EEC of 22 July 1991 laying down the health conditions for the production and the placing on the market of fishery products. Official Journal $L$, 268, 0015-0034.

15. FDA (2011). Fish and Fishery Products Hazards and Controls Guidance. (http://www.fda.gov/downloads/Food/GuidanceRegul ation/UCM251970.pdf).

16. Fraser, O.P., Sumar, S. (1998). Compositional changes and spoilage in fish (part II)-microbiological induced deterioration. Journal of Nutrition \& Food Sciences, 98, 325-329.

17. Gökoglu, N., Cengiz, E., Yerlikaya, P. (2004). Determination of shelf-life of marinated sardine (Sardina pilchardus) stored at $4{ }^{\circ} \mathrm{C}$. Food Control, $15,1-4$.

18. Goulas, E., Kontominas, I., Chouliara, E., Nessi, G., Savvaidis, I. (2005). Microbiological, biochemical and sensory assessment of mussels (Mytilus galloprovincialis) stored under modified atmosphere packaging, Journal of Applied Microbiology, 98, 752760.

19. Günşen, U., Özcan, A., Aydin, A. (2011). Determination of some quality criteria of cold storaged marinated anchovy under vacuum and modified atmosphere conditions. Turkish Journal of Fisheries and Aquatic Sicences, 11, 233-242.

20. Howgate, P. (2010). A critical review of total volatile bases and trimethylamine as indices of freshness of fish. Part 1. Determination. Electronic Journal of Environmental, Agricultural and Food Chemistry, 9, 2957.

21. İnal, T. (1992). Besin Hijyeni. Hayvansal Gıdalarda Kalite Kontrol. Final Ofset, İstanbul.

22. Ivanović, J., Đurić, J., Bošković, M., Marković, R. Baltić, Ž.M., Đorđević, V., Grbić, S. (2014). The effect of salting and marinating on microbiological status and chemical composition of mackerel packed in the modified atmosphere. Tehnologija mesa, 55, 169-175.

23. Ivanović, J., Janjić, J., Đorđević, V., Dokmanović, M., Bošković, M., Marković, R., Baltić, M. (2015). The effect of different packaging conditions, $\mathrm{pH}$ and Lactobacillus spp. on the growth of Yersinia enterocolitica in pork meat. Journal of Food Processing and Preservation, 39, 2773-2779.

24. Keskin, H. (1982). Besin kimyası. İstanbul Üniversitesi Mühendislik Fakültesi.

25. Kilinc, B., Cakli, S. (2004). Chemical, microbiological and sensory changes in thawed frozen fillets of sardine (Sardina pilchardus) during marination. Food Chemistry, 88, 275-280.

26. Kilinc, B., Cakli, S. (2005). Determination of the shelflife of sardine (Sardina pilchardus) marinades bacterial isolation in canned anchovies recalled by the USFDA. Journal of Food Science, 69, 157-162.

27. Kim, Y.M., Paik, H.D., Lee, D.S. (2002). Shelf-life characteristics of fresh oysters and ground beef as affected by bacteriocin-coated plastic packaging film. Journal of the Science of Food and Agriculture, 82, 998-1002.

28. Koral, S., Sevim, K., Bekir, T. (2010). The effect of storage temperature on the chemical and sensorial quality of hot smoked Atlantic Bonito (Sarda sarda, Bloch, 1838) packed in aluminium foil. Turkish Journal of Fisheries and Aquatic Sicences, 10, 439-443.

29. Lehane, L., Olley, J. (2000). Histamine fish poisoning revisited. International Journal of Food Microbiology, $58,1-37$

30. Lopez-Caballero, M.E., Perez-Mateos, M., Montero, P., Borderias, A.J. (2000). Oyster preservation by high pressure treatment. Journal of Food Protection, 63, 196-201.

31. Losada, V., Pineiro, C., Rodriguez, O., Antonio, J., Barros- Velazquez, J., Auboutg, S. (2003). Improvement of horse mackerel (Trachurus trachurus) quality during chilling storage by flow ice application. Assessment of Chemical Changes, 31, 329-333.

32. Luong, J.H.T., Male, K.B., Masson, C., Nguyen, A.L. (1992). Hypoxanthine ratio determination in fish extract using capillary electrophoresis and immobilized enzymes. Journal of Food Science, 54, 77-81.

33. Mackie, I.M., Pirie, L., Ritchie, A.H., Yamanaka, H. (1997). The formation of non-volatile amines in relation to concentration of free basic amino acid during postmortem storage of the muscle of scallop (Pecten maximus), herring (Clupea harengus) and mackerel (Scomber scombrus). Food Chemistry, 60, 291-295.

34. Mbarki, R., Miloud, N.B., Selmi, S., Dhib, S., Sadok, S. (2009). Effect of vacuum packaging and low-dose irradiation on the microbial, chemical and sensory characteristics of chub mackerel (Scomber japonicus). Food Microbiology, 26, 821-826.

35. Mendes, R., Goncalves, A. (2008). Effect of soluble $\mathrm{CO}_{2}$ stabilisation and vacuum packaging in the shelf life of farmed sae bream and sea bass fillets. International Journal of Food Science \& Technology, 43, 1678-1687.

36. Özoğul, F., Taylor, K.D.A., Quantick, P., Özoğul, Y. (2002). Biogenic amines formation in Atlantic herring (Clupea harengus) stored under modified atmosphere packaging using a rapid HPLC method. International Journal of Food Science \& Technology, 37, 515-522

37. Özoğul, F., Taylor, K.D, Quantick, T.P, Özoğul, Y. (2008). Changes in biogenic amines in herring stored uder modified atmosphere and vacuum pack. Journal of Food Science, 67, 2497-2501.

38. Patange, S.B., M.K. Mukundan, Ashok Kumar, K. (2005). A simple and rapid method for colorimetric determination of histamine in fish flesh. Food Control, 16, 465-472.

39. Poligne, I., Collignan, A. (2000). Quick marination of anchovies (Engraulis enchrasicolus) using acetic and gluconic acids. Quality and stability of the end product. Lebensmittel Wissenschaft und Technologie, 33, 202-209.

40. Pons-Sánchez-Cascado, S. (2005). Influence of the freshness grade of raw fish on the formation of volatile and biogenic amines during the manufacture and storage of vinegar-marinated anchovies. Journal of Agricultural and Food Chemistry, 53, 8586-8592.

41. Rivas, B., Gonzalez, R., Landete, J.M, Munoz, R. (2008). Characterization of a second ornithine decarboxylase isolated from Morganella morganii. Journal of Food Protection, 3, 657-61.

42. Sallam, K., Ahmed, A.M., Elgazzar, M.M, Eldaly, E. (2007). Chemical quality and sensory attributes of marinated pacific saury (Cololabis saira) during vacuum-packaged storage at $4{ }^{\circ} \mathrm{C}$. Food Chemistry, 102, 1061-1070.

43. Sandhya, J. (2010). Modified atmosphere packaging of fresh produce: Current status and future needs. Journal of Food Science and Technology, 43, 381392.

44. Shimizu, Y., Toyohara H., Lanier T.C. (1992). Surimi production from fatty and dark-fleshed fish species. In Surimi Technology. Eds. T.C. Lanier, C. M. Lee, CRC Press, New York, 181-207.

45. Sainclivier, M. (1983). L'industrie alimentaire halieutique. Premier volume: le poisson matière première. Bulletin Scientifique et Technique de l'Ecole Nationale Supérieure Agronomique et du Centre de Recherches de Rennes, Sciences Agronomiques Rennes, Rennes, France.

46. Schormüller, J. (1969). Handbuch der Lebensmittelchemie (Band III/2). Triesrische Lebensmittel Eier, 
Jelena Ivanović et al., Effect of modified atmosphere and vacuum packaging conditions on selected chemical and physicochemical parameters of marinated and salted Atlantic mackerel (Scomber scombrus),

Food and Feed Research, 43 (1), 111-118, 2016

Fleisch, Fisch, Buttermich, Springer Verlag, Berlin/Heidelberg, Germany/New York, NY. 1584.

47. Siverstvik, M. (2007). The optimized modified atmosphere for packaging of pre-rigor filleted farmed cod (Gadhus morhua) is $63 \mathrm{ml} / 100 \mathrm{ml}$ oxygen and $37 \mathrm{ml}$ / $100 \mathrm{ml}$ carbon dioxide. LWT-Food Science and Technology, 40, 430-438.

48. Smith, G., Hole M., Hanson, S.W. (1992). Assessment of lipid oxidation in Indonesian salted-dried marine catfish (Arius thalassinus). Journal of the Science of Food and Agriculture, 51, 193-205.

49. Stamatis, N., Arkoudelos, J. (2007). Quality assessment of Scomber colias japonicus under modified atmosphere and vacuum packaging. Food Control, $18,292-300$
50. Tarladgis, B.G., Watts, B.M., Dugan, L.R. (1960). A distillation method for the quantitative determination of malonaldehyde in rancid foods. Journal of the American Oil Chemists' Society, 37, 44-48.

51. Tozawa, H., Erokibara, K., Amano, K. (1971). Proposed modification of Dyer's method for trimethylamine determination in codfish. Fish Inspection and Quality Control, 187-190.

52. Varlik, C. Uğur, M., Gökoğlu, N., Gün, H. (1993). Su Ürünlerinde Kalite Kontrol. Gıda Teknolojisi Derneği Yayın No17, İstanbul.

53. Watts, D.A., Brown, W.D. (1982). Histamine formation in abusively stored Pacific mackerel: effect of $\mathrm{CO}_{2}$ modified atmosphere. Journal of Food Science, 47, 1386-1387.

\title{
УТИЦАЈ ПАКОВАЊА У МОДИФИКОВАНОЈ АТМОСФЕРИ И ВАКУУМУ НА ОДАБРАНЕ ХЕМИЈСКЕ И ФИЗИЧКО-ХЕМИЈСКЕ ПАРАМЕТРЕ МАРИНИРАНЕ И СОЉЕНЕ СКУШЕ \\ (Scomber scombrus)
}

\author{
Јелена С. Ивановић ${ }^{1 *}$, Јелена М. Јањић ${ }^{1}$, Славен М. Грбић ${ }^{2}$, Јасна П. Ђорђевић ${ }^{1}$, Наташа М. \\ Гламочлија ${ }^{1}$, Татјана М. Балтић ${ }^{3}$, Радмила В. Марковић ${ }^{1}$, Марија Д. Бошковић ${ }^{1}$, Милан ж. \\ Балтић ${ }^{1}$ \\ ${ }^{1}$ Катедра за хигијену и технологију намирница анималног порекла, Факултет ветеринарске \\ медицине, Универзитет у Београду, Булевар ослобођења 18, 11000 Београд, Србија \\ ${ }^{2}$ Славен д.о.о, Бања Лука, Босна и Херцеговина \\ ${ }^{3}$ Институт за хигијену и технологију меса, Каћанског 13, 11000 Београд, Србија
}

Сажетак: Циљ овог рада је био испитивање хемијских и физичко-хемијских параметара мариниране и сољене скуше (Scomber scombrus), са посебним освртом на параметре квалитета и безбедности скуше паковане у модификованој атмосфери (МАП) и вакуум паковању (ВП). Оцена квалитета скуше која је пакована у МАП (40\% CO2 + 60\% N2) и ВП у трајању до 50 дана на $4 \pm 1^{\circ} \mathrm{C}$ вршена је праћењем промена $\mathrm{pH}$ вредности, укупног испарљивог азота (TVB-N), тиобарбитурне киселине (ТВА) и садржаја хистамина. Вредност рН рибљег меса је знатно нижа у маринираним узорцима скуше. Највећа концентрација TVB-N је забележена код сољених узорака скуше који су паковани у вакууму, а најнижа концентрација TVB-N је забележена код узорака рибе пакованих у МАП (маринирана скуша). Формирање ТВА повећава се са временом складиштења, а ова вредност је била најнижа у узорцима мариниране скуше паковане у МАП-у. Концентрација хистамина се повећава током складиштења, а његов садржај био је преко $10 \mathrm{mg} /$ $100 \mathrm{~g}$ само за сољену скушу паковану у вакууму. У односу на физичко-хемијске анализе узорака скуше, резултати овог испитивања показују да маринирана скуша пакована у МАП, има дужи рок употребе у односу на узорке скуше пакаване у вакууму.

Кључне речи: Скуша, хистамин, $p H$ вредност, TBA, TVB-N

Received: 14 March 2016

Accepted: 23 June 2016 